\title{
Chemical profile of sugarcane spirits produced by double distillation methodologies in rectifying still
}

\author{
Aspectos da composição química de aguardente de cana-de-açúcar \\ produzida por metodologias de dupla destilação em alambique retificador
}

\author{
André Ricardo ALCARDE ${ }^{1 *}$, Paula Araújo de SOUZA ${ }^{1}$, André Eduardo de Souza BELLUCO ${ }^{1}$
}

\begin{abstract}
The objective of this study was to determine the chemical profile of sugarcane spirits produced by different double distillation methodologies in rectifying still. Fermented sugarcane juice was distilled in rectifying still according to three double distillation methodologies: the methodology used for cognac production; the methodology used for whisky production; and the 10-80-10 percentage composition methodology, referring to the volumes of head, heart and tail of the distillate fractions from the second distillation. For comparison purposes, a simple distilled spirit was also produced. The distillates were analyzed for concentrations of ethanol, copper, volatile acidity, furfural and hydroxymethylfurfural, aldehydes, esters, methanol and higher alcohols. The spirits were also evaluated on the sensory attributes of aroma, taste and preference. Compared to simple distillation, double distillation improved the chemical quality of the spirits, since it has reduced the concentrations of acids, aldehydes, esters, methanol, higher alcohols and, consequently, their coefficient of congeners. Regardless of the methodology employed, the double distillation improved the sensory quality of the spirits since they obtained higher sensory acceptance in relation to spirits produced by simple distillation. Among double distilled spirits, the one produced according to whisky methodology obtained the best scores from appraisers on the aroma and flavor parameters and it was also the most preferred.

Keywords: alcoholic beverage; sugarcane spirit; double distillation; rectifying still.
\end{abstract}

\section{Resumo}

O objetivo deste trabalho foi determinar o perfil físico-químico da aguardente de cana-de-açúcar produzida por diferentes metodologias de dupla destilação em alambique retificador. Mosto fermentado de caldo de cana-de-açúcar foi destilado seguindo três metodologias de dupla destilação: a empregada para a produção de cognac, a empregada na produção de whisky e a metodologia da proporção porcentual 10-80-10, referente aos volumes das frações cabeça, coração e cauda do destilado. Para comparação, também foi produzida uma aguardente monodestilada. Os destilados foram analisados quimicamente quanto às concentrações de etanol, cobre, acidez volátil, furfural e hidroximetilfurfural, aldeídos, ésteres, metanol e álcoois superiores. As aguardentes foram também avaliadas sensorialmente quanto aos atributos de aroma, sabor e preferência. Comparada com a monodestilação, a dupla destilação melhorou a qualidade química das aguardentes, pois proporcionou redução das concentrações de ácidos, de aldeídos, de ésteres, de metanol, de álcoois superiores e, consequentemente, do coeficiente de congêneres das aguardentes. Independentemente da metodologia empregada, as aguardentes produzidas por dupla destilação obtiveram maior aceitação sensorial que a aguardente monodestilada. Dentre as aguardentes duplamente destiladas, a produzida segundo a metodologia do uísque obteve as maiores notas dos provadores quanto aos parâmetros de aroma e sabor e também foi a preferida.

Palavras-chave: bebida alcoólica; aguardente de cana-de-açúcar; dupla destilação, alambique retificador.

\section{Introduction}

Sugarcane spirit is a drink with alcoholic degree ranging from 38 to $54 \%(\mathrm{v} / \mathrm{v})$ at $20^{\circ} \mathrm{C}$, obtained from the distillation of fermented sugarcane juice (BRASIL, 2005a).

The sugarcane spirits are submitted to national legislation (BRASIL, 2005a), which is under the responsibility of the Ministry of Agriculture, Livestock and Supply (MAPA), which establishes the chemical composition and quality requirements of the beverage (Table 1).

These standards and their limits have the purpose of controlling the influence of each of these components in the quality of the drink and of protecting public health, what does not mean, however, that the spirit that fits these patterns can be considered a product of higher sensory quality.

For the distillation of the fermented sugarcane juice (wash), large producers use conventional distillation columns, in continuous process. Small and medium producers carry out distillation in stills. In practice, these producers do not usually separate the distillate fractions. Some producers remove a small fraction, the "head", and the minority performs the double distillation. However, the double distillation methodology employed by these few producers does not seem to be the most suitable when aimed at the quality of the distillate. According

Received 15/4/2009

Accepted 18/1/2010 (004161)

Departamento de Agroindústria, Alimentos e Nutrição, Escola Superior de Agricultura "Luiz de Queiroz" - ESALQ, Universidade de São Paulo - USP, Av. Pádua Dias, 11,

CP 9, CEP 13418-900,

Piracicaba - SP, Brasil, E-mail: aralcard@esalq.usp.br

${ }^{*}$ Corresponding autor 
Table 1. Identity and quality standards for sugarcane spirits established by the Brazilian law.

\begin{tabular}{|c|c|c|c|}
\hline \multirow[t]{2}{*}{ Component } & \multirow[t]{2}{*}{ Unit } & \multicolumn{2}{|c|}{ Limits } \\
\hline & & minimum & maximum \\
\hline Volatile acidity (acetic acid) & mg.100 $\mathrm{mL}^{-1}$ anhydrous alcohol & - & 150 \\
\hline Esters (ethyl acetate) & mg.100 mL $\mathrm{m}^{-1}$ anhydrous alcohol & - & 200 \\
\hline Furfural and hydroximetilfurfural & mg.100 mL $\mathrm{m}^{-1}$ anhydrous alcohol & - & 5 \\
\hline High alcohols ${ }^{1}$ & mg.100 mL $\mathrm{m}^{-1}$ anhydrous alcohol & - & 360 \\
\hline Copper & mg. $\mathrm{L}^{-1}$ & - & 5 \\
\hline
\end{tabular}

${ }^{1}$ High alcohols = total of iso-butyl alcohol (2-methyl-propanol), isoamyl alcohols (2-methyl-1-butanol and 3-methyl-1-butanol) and n-propyl alcohol (1-propanol). ${ }^{2}$ Congeners = total of volatile acidity, esters, aldehydes, furfurals and high alcohols.

to this methodology (NOVAES, 1997), in the first distillation, the wash is distilled to recover the entire ethanol. Then, in the second distillation, the following "cuts" in distillate are obtained: "head" fraction (initial 10\% of the distillate volume), "heart" fraction or spirits ( $80 \%$ of the distillate volume) and "tail" fraction (final $10 \%$ of the distillate volume).

Cognac and whisky production processes use other double distillation methodologies (LÉAUTÉ, 1990; PIGGOTT; CONNER, 2003), which, according to literature, are the most suitable when aimed at the chemical and sensory quality of the final distillate.

For cognac, the first distillation separates "head" $(0.4 \%$ of the wine volume), "heart" or "brouillis" (distillate collected after "head" fraction and until the distillate presents $5 \%$ of alcohol) and "tail" (distillate collected from 5 to $0 \%$ of alcohol) fractions. In the second distillation, the brouillis is divided into four fractions: "head" (1.0\% of the brouillis volume), "heart 1" or cognac (distillate collected after the "head" fraction and until the distillate presents $60 \%$ of alcohol), "heart 2" (distillate collected between 60 and $5 \%$ of alcohol) and "tail" (distillate collected between 5 and $0 \%$ of alcohol) (LÉAUTÉ, 1990).

For whisky, the first distillation recovers the ethanol from wash, without "cuts" of fractions, originating the "low wines". In the second distillation, the "low wines" is distilled with the separation of "head" ( $2 \%$ of the low wines volume, recovered usually from 78 to $75^{\circ} \mathrm{GL}$ ), "heart" or whisky (distilled recovered from 75 to $60^{\circ} \mathrm{GL}$ ) and "tail" (distillate recovered from 60 to $0^{\circ} \mathrm{GL}$ ) (PIGGOTT; CONNER, 2003).

The objective of this study was to determine the chemical profile of sugarcane spirits produced by different double distillation methodologies in rectifying still and verify its influence on the sensory quality of the distillate.

\section{Materials and methods}

Whole sugarcane stalks of the variety SP80-3280 were milled to extract the juice. The extracted juice was filtered on cotton, boiled for 10 minutes, cooled, filtered again and diluted to $18^{\circ}$ Brix. The juice was inoculated with Saccharomyces cerevisiae yeasts (strain Y-904) in the form of dried live yeast.
The fermentation was conducted in stainless-steel tanks with $13 \mathrm{~L}$ of useful capacity. The fermentation temperature was controlled between 28 and $30^{\circ} \mathrm{C}$ through a thermostatic bath. The fermentations started with $3 \mathrm{~g}$ of dry yeast per liter of juice. The yeast was recycled for two further fermentative cycles by decantation.

The distillation was conducted in rectifying still with gas heating system, copper boiler with $37 \mathrm{~L}$ of useful capacity, stainless steel rectifying column with four trays and stainless steel condenser (Figure 1).

Three double distillation methodologies were studied. The first one was the methodology commonly used in industrial stills (NOVAES, 1997), in which the first distillation virtually recovered all the ethanol from the wash, i.e., the wash was distilled until the alcoholic degree of the distillate in the condenser outlet reached the value of $3 \%$ of ethanol $(\mathrm{v} / \mathrm{v})$. The distillate recovered from the first distillation followed to the second distillation, which carried out the separation of fractions; according to the 10-80-10 percentage composition methodology, referring to the volume of "head", "heart" and "tail" fractions from the second distillate. The "heart" fraction was the spirits itself.

The second double distillation methodology employed was the same used for the cognac production (LÉAUTÉ, 1990). The first distillation produced a distillate called brouillis. In this first distillation, the distillate was divided into three fractions: "head", "heart" (brouillis) and "tail." The "head" fraction was equivalent to $0.4 \%$ of the volume of the wash added in the distiller boiler. The brouillis was the distillate collected after the "head" fraction until the distillate in the condenser outlet presented $5 \%$ of alcohol (v/v). The "tail" fraction was the distillate collected after brouillis. The brouillis was used for the second distillation. Three batches of first distillations were required to produce enough volume of brouillis for the second distillation. In the second distillation, the brouillis was distilled and divided into four fractions: "head", "heart 1" "heart 2" and "tail." The "head" fraction of the second distillation was equivalent to $1.0 \%$ of the brouillis volume added to the boiler. The "heart 1" fraction was the distillate collected after the "head" fraction until the distillate 
in the condenser outlet presented $60 \%$ of alcohol (v/v). The "heart 2" fraction was the distillate collected between 60 and 5\% of alcohol (v/v). The "tail" fraction was the distillate collected after the "heart 2" fraction. The "heart 1" fraction corresponded to the spirit produced using the cognac methodology.

The third double distillation methodology employed was that used for the whisky production (PIGGOTT; CONNER, 2003). The first distillation virtually extracted all the alcohol from the wash, that is, until the distillate in the condenser outlet presented $3^{\circ} \mathrm{GL}$ measured in alcoholmeter. The distillate of the first distillation, called "low wines" followed for the second distillation. Three batches of first distillations were required to produce enough volume of "low wines" for the second distillation. In the second distillation, the "low wines" was distillated and divided into three fractions: "head", "heart" and "tail." The "head" fraction was equivalent to $2.0 \%$ of the "low wines" volume added to the boiler. The "heart" fraction was the distillate collected after the "head" fraction, until the distillate in the condenser outlet presented $60 \%$ of alcohol (v/v). The "tail" fraction was the distillate collected after the "heart" fraction. The "heart" fraction was the spirit produced using the whisky methodology.

In order to obtain another standard for comparison purposes, a simple distilled spirit was also produced. According to this distillation methodology (NOVAES, 1997), the alcoholic vapors from the distillation of wash were collected until the overall distillate presented an average alcohol degree of approximately $43^{\circ} \mathrm{GL}$.

The distillate fractions from the first and second distillations were analyzed for the concentration of ethanol, volatile acidity, furfural, hydroxymethylfurfural and copper, according to the official methodologies described in Brasil (2005b).

The analyses of esters, aldehydes, higher alcohols and methanol were performed using a GC-037 gas chromatograph equipped with a PAAC 3334-GC packed column and a flameionization detector (FID). $\mathrm{H} 2$ was used as carrier gas, with a flow rate of $30 \mathrm{~mL} / \mathrm{min}$. The injector temperature was adjusted to $170^{\circ} \mathrm{C}$. The column temperature programming was isothermic at $94{ }^{\circ} \mathrm{C}$. The detector temperature was adjusted to $225^{\circ} \mathrm{C}$.

The spirits were sensory evaluated by analysis of aroma, taste and preference, by a team of 30 untrained tasters, using a 9-point hedonic scale (approved by Ethics Committee Research, number FR 202278). The samples were presented to the tasters according to procedures described by Macfie and Bratchell (1989).

The statistical analysis of data consisted of analyses of variance and Tukey's test at 5\% significance (PIMENTELGOMES; GARCIA, 2002), using the SAS statistical program (STATISTICAL..., 1996).
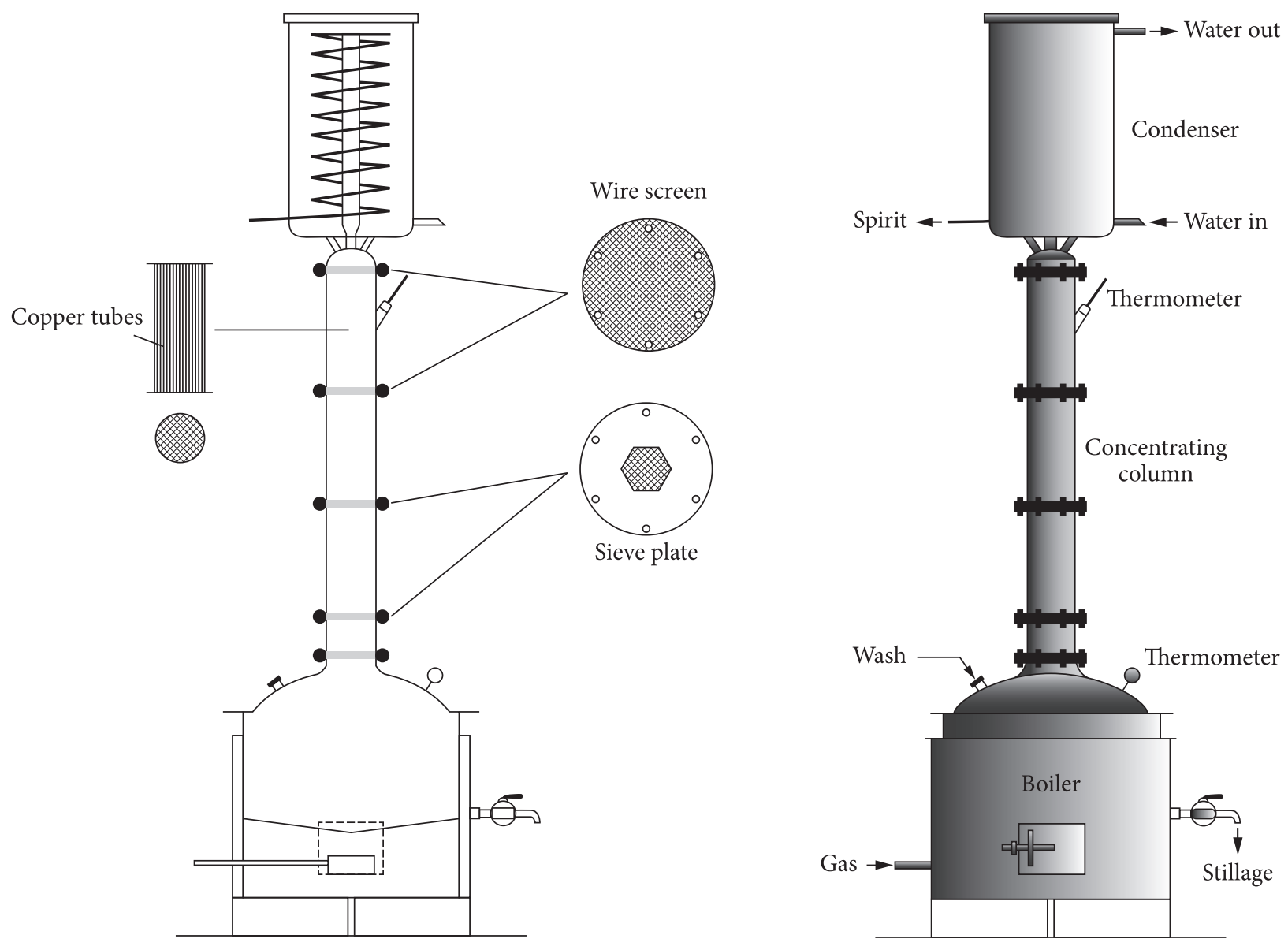

Figure 1. Rectifying still used in the experiment. 


\section{Results and discussion}

Compared to simple distillation, double distillation, in spite of the methodology, has reduced the concentrations of volatile acidity, aldehydes, esters, methanol, higher alcohols, and consequently, the congeners of the produced spirits.

Considering the chemical composition of the spirit produced using simple distillation methodology (Table 2), the double distillation methodologies based on cognac (Table 4) and

Table 2. Chemical composition of the spirit obtained using simple distillation methodology.

\begin{tabular}{lrr}
\hline & Spirit & \multicolumn{1}{c}{ Tail } \\
\hline Alcoholic concentration $^{1}$ & 43.31 & 15.33 \\
Copper $^{2}$ & 0.05 & 0.16 \\
Volatile acidity $^{3}$ & 59.74 & 335.28 \\
Furfural $^{3}$ & 0.01 & 0.24 \\
Aldehydes $^{3}$ & 33.51 & 3.31 \\
Esters $^{3}$ & 34.29 & 1.01 \\
Methanol $^{3}$ & 11.30 & 7.68 \\
High alcohols $^{3}$ & 680.60 & 73.59 \\
Congeners $^{3}$ & 808.15 & 413.43 \\
\hline
\end{tabular}

${ }^{1}$ in $\% \mathrm{v} / \mathrm{v} 20{ }^{\circ} \mathrm{C} ;{ }^{2}$ in ppm; ${ }^{3} \mathrm{mg} .100 \mathrm{~mL}^{-1}$ anhydrous alcohol.

Table 3. Chemical composition of the distillate fractions from the first and second distillations, according to double distillation methodology based on the 10-80-10 percentage composition.

\begin{tabular}{lrrrr}
\hline & First & \multicolumn{3}{c}{ Second distillation } \\
\cline { 3 - 5 } & distillation & Head & $\begin{array}{c}\text { Heart } \\
\text { (Spirit) }\end{array}$ & Tail \\
\hline Alcoholic concentration $^{1}$ & 39.16 & 83.60 & 69.57 & 6.55 \\
Copper $^{2}$ & 0.07 & 0.12 & 0.11 & 0.10 \\
Volatile acidity $^{3}$ & 31.33 & 7.23 & 25.45 & 323.63 \\
Furfural $^{3}$ & 0.16 & 0.04 & 0.31 & 0.91 \\
Aldehydes $^{3}$ & 23.71 & 57.33 & 14.02 & 0.00 \\
Esters $^{3}$ & 21.37 & 53.93 & 13.98 & 0.00 \\
Methanol $^{3}$ & 14.24 & 64.62 & 9.22 & 5.83 \\
High alcohols $^{3}$ & 551.64 & 608.85 & 606.79 & 17.47 \\
Congeners $^{3}$ & 628.21 & 727.38 & 660.55 & 342.01 \\
\hline
\end{tabular}

${ }^{1}$ in $\% \mathrm{v} / \mathrm{v} 20^{\circ} \mathrm{C} ;{ }^{2}$ in ppm; ${ }^{3} \mathrm{mg} .100 \mathrm{~mL}^{-1}$ anhydrous alcohol. whisky (Table 5) provided greater reduction in the concentration of secondary compounds of spirits when compared to the 10-80-10 percentage composition methodology (Table 3), especially for concentrations of volatile acidity, aldehydes, esters, higher alcohols and congeners (Table 6).

When a second distillation is conducted, part of the water in the wash has already been removed by the first distillation, concentrating the distillate of the first distillation in ethanol and volatile secondary compounds. Therefore, the purpose of the second distillation is to remove contaminants and to reduce the concentrations of secondary compounds in order to improve the quality of the distillate and make it suitable to legislation.

Accordingly, taking as reference the chemical composition of the distillates of the first distillations, the double distillation methodologies based on the cognac and whisky production provided greater reduction in the concentration of secondary compounds of spirits than the 10-80-10 percentage composition methodology - especially for concentrations of volatile acidity, aldehydes, esters, methanol, higher alcohols and congeners (Table 7). In addition, the second distillation of 10-80-10 percentage composition methodology resulted in increased concentration of higher alcohols and congeners in the spirits.

Acetic acid is an important compound for the quality of sugarcane spirits, since the lower the acidity of the drink, the better its acceptance by consumers (MIRANDA et al., 2008).

As for aldehydes, a low content in beverages is frequently associated with an improvement in quality, since they are usually associated with intoxication and "hangover" symptoms such as nausea, vomiting, restlessness, sweating, confusion, decrease in blood pressure, higher heart rate and headache (NASCIMENTO et al., 1997). Acetaldehyde and other short-chain aliphatic aldehydes have pungent odor, which may increase the tang of distilled beverages (NYKÄNEN, 1986; RODRÍGUEZ; MANGAS, 1996). In general, aldehydes with up to eight carbon atoms, such as acetaldehyde $(\mathrm{C} 2 \mathrm{H} 4 \mathrm{O})$, formaldehyde $(\mathrm{CH} 2 \mathrm{O})$, acrolein $(\mathrm{C} 3 \mathrm{H} 4 \mathrm{O})$, benzaldehyde $(\mathrm{C} 7 \mathrm{H} 6 \mathrm{O})$ and furfural (C5H4O2), have penetrating odors, generally sickening, which are considered undesirable in spirits. On the other hand, larger aldehydes, which contain up to ten carbon atoms, have pleasant aroma (MAIA, 1994). In the same way, esters are usually desirable because they improve the flavor of spirits.

Table 4. Chemical composition of the distillate fractions obtained in the first and second distillations, according to double distillation methodology used in the cognac production.

\begin{tabular}{|c|c|c|c|c|c|c|c|}
\hline & \multicolumn{3}{|c|}{ First distillation } & \multicolumn{4}{|c|}{ Second distillation } \\
\hline & Head & Brouillis & Tail & Head & Heart 1 (Spirit) & Heart 2 & Tail \\
\hline Alcoholic concentration $^{1}$ & 81.10 & 41.39 & 1.85 & 84.15 & 80.32 & 31.86 & 3.25 \\
\hline Copper $^{2}$ & 0.18 & 0.10 & 0.15 & 0.14 & 0.06 & 0.38 & 0.15 \\
\hline Volatile acidity ${ }^{3}$ & 11.41 & 29.42 & 642.16 & 7.41 & 11.09 & 55.93 & 639.69 \\
\hline Furfural $^{3}$ & 0.00 & 0.00 & 0.00 & 0.00 & 0.00 & 0.00 & 0.00 \\
\hline Aldehydes ${ }^{3}$ & 101.17 & 19.25 & 0.00 & 88.01 & 9.42 & 0.00 & 0.00 \\
\hline High alcohols ${ }^{3}$ & 987.19 & 497.91 & 12.33 & 460.67 & 448.51 & 81.95 & 0.00 \\
\hline Congeners $^{3}$ & 1278.88 & 565.81 & 654.49 & 627.47 & 477.7 & 137.88 & 639.69 \\
\hline
\end{tabular}

${ }^{1}$ in $\% \mathrm{v} / \mathrm{v} 20^{\circ} \mathrm{C} ;{ }^{2}$ in ppm; ${ }^{3} \mathrm{mg} .100 \mathrm{~mL}^{-1}$ anhydrous alcohol. 
Methanol is an undesirable alcohol in spirits because it may cause toxic symptoms such as headache, dizziness, vomiting and diverse pain, and its intake for long periods, even in small doses, can lead to blindness and even death (LAMIABLE et al., 2004; GEROYIANNAKI et al., 2007).

From the quantitative point of view, the formation of higher alcohols depends mainly on the yeast strain used. Due to the characteristic aroma, higher alcohols have a strong influence on the taste of spirits. Higher alcohols, with three to five carbons, have characteristic odors, traditionally associated with spirits. Above five carbons, these alcohols become oily, and some of them recall the smell of flowers (MAIA, 1994).

The spirits produced by simple distillation (Table 2) were out of the standards set by legislation in force (Table 1) for the concentrations of aldehydes, higher alcohols and congeners.

The alcoholic concentration of spirits produced by double distillation methodology (Tables 3, 4 and 5) are above the maximum levels allowed by the Brazilian legislation (38 to $54 \% \mathrm{v} / \mathrm{v})$. The first distillations, which started from a wash with about $10 \%(\mathrm{v} / \mathrm{v})$ of ethanol, provided the concentration of the distillate up to $32-35 \%$ of ethanol $(\mathrm{v} / \mathrm{v})$, depending on the double distillation methodology used. Thus, second distillations, which started from alcoholic mixtures with 32-35\% (v/v) of alcohol, produced spirits with alcohol concentration above $54 \%(\mathrm{v} / \mathrm{v})$. However, this would not be a problem, since the aging of spirits in wooden barrels could attenuate its alcoholic concentration and also, spirits could be diluted with potable water to alcoholic concentrations within the limits set by law.

The concentrations of secondary compounds of spirits produced by double distillation processes (Tables 3, 4 and 5) are in accordance with the Brazilian legislation (Table 1), except for higher alcohols. However, the concentration of higher alcohols, within certain limits, does not seem to be a parameter that negatively affects the quality of spirits, since single malt whisky and cognac analysis showed that they had higher alcohol concentrations - from 438 to $478 \mathrm{mg} .100 \mathrm{ml}^{-1}$ of anhydrous alcohol (Table 8).

Regardless the methodology employed, the spirits produced by double distillation obtained higher sensory acceptance when compared to spirits produced by simple distillation. Among spirits produced by double distillation, those produced according to the methodology used for whisky production obtained the best scores from appraisers for the aroma and flavor parameters and were also the most preferred. Spirits produced using the 10-80-10 methodology received the worst scores among the spirits produced by double distillation (Table 9 ).
Table 5. Chemical composition of distillate fractions from the first and the second distillations, according to double distillation methodology used in the whisky production.

\begin{tabular}{lrrcr}
\hline & Low wines & \multicolumn{3}{c}{ Second distillation } \\
\cline { 3 - 5 } & & Head & Heart (Spirit) & \multicolumn{1}{c}{ Tail } \\
\hline Alcoholic & 39.84 & 84.19 & 78.55 & 35.09 \\
concentration $^{1}$ & & & & \\
Copper $^{2}$ & 0.09 & 0.13 & 0.08 & 0.13 \\
Volatile acidity $^{3}$ & 39.82 & 7.06 & 7.56 & 42.32 \\
Furfural $^{3}$ & 0.10 & 0.00 & 0.00 & 0.00 \\
Aldehydes $^{3}$ & 21.11 & 76.25 & 9.60 & 0.00 \\
Esters $^{3}$ & 20.84 & 75.24 & 10.39 & 0.00 \\
Methanol $^{3}$ & 14.60 & 92.32 & 9.45 & 6.06 \\
High alcohols $^{3}$ & 548.19 & 455.87 & 401.90 & 180.79 \\
Congeners $^{3}$ & 630.06 & 614.42 & 429.45 & 223.11 \\
\hline
\end{tabular}

${ }^{1}$ in $\% \mathrm{v} / \mathrm{v} 20^{\circ} \mathrm{C} ;{ }^{2}$ in ppm; ${ }^{3} \mathrm{mg} \cdot 100 \mathrm{~mL}^{-1}$ anhydrous alcohol.

Table 6. Percentage of reduction in the concentration of secondary compounds of spirits produced by double distillation, taking as reference the concentration of secondary compounds in the spirit produced by simple distillation methodology.

\begin{tabular}{lccc}
\hline & \multicolumn{3}{c}{ Methodology of double distillation } \\
\hline & $10-80-10$ & Cognac & Whisky \\
\hline Volatile acidity $^{1}$ & $57^{\mathrm{b}}$ & $81^{\mathrm{a}}$ & $87^{\mathrm{a}}$ \\
Aldehydes $^{1}$ & $58^{\mathrm{b}}$ & $72^{\mathrm{a}}$ & $71^{\mathrm{a}}$ \\
Esters $^{1}$ & $59^{\mathrm{b}}$ & $75^{\mathrm{a}}$ & $70^{\mathrm{a}}$ \\
Methanol $^{1}$ & $18^{\mathrm{ab}}$ & $26^{\mathrm{a}}$ & $16^{\mathrm{b}}$ \\
High alcohols $^{1}$ & $11^{\mathrm{c}}$ & $34^{\mathrm{b}}$ & $41^{\mathrm{a}}$ \\
Congeners $^{1}$ & $18^{\mathrm{b}}$ & $41^{\mathrm{a}}$ & $47^{\mathrm{a}}$ \\
\hline
\end{tabular}

${ }^{1} \mathrm{mg} .100 \mathrm{~mL}^{-1}$ anhydrous alcohol. Different letters in same row indicate statistical difference by Tukey's test at $5 \%$ significance.

Table 7. Percentage of reduction in the concentration of secondary compounds of the spirits produced by double distillation, taking as reference the concentration of secondary compounds in the distillate of the first distillation.

\begin{tabular}{lccc}
\hline & \multicolumn{3}{c}{ Methodology of double distillation } \\
\hline & $10-80-10$ & Cognac & Whisky \\
\hline Volatile acidity $^{1}$ & $19^{\mathrm{c}}$ & $62^{\mathrm{b}}$ & $81^{\mathrm{a}}$ \\
Aldehydes $^{1}$ & $41^{\mathrm{b}}$ & $51^{\mathrm{ab}}$ & $55^{\mathrm{a}}$ \\
Esters $^{1}$ & $35^{\mathrm{b}}$ & $55^{\mathrm{a}}$ & $50^{\mathrm{a}}$ \\
Methanol $^{1}$ & $35^{\mathrm{a}}$ & $33^{\mathrm{a}}$ & $35^{\mathrm{a}}$ \\
High alcohols $^{1}$ & $-10^{\mathrm{c}}$ & $10^{\mathrm{b}}$ & $27^{\mathrm{a}}$ \\
Congeners $^{1}$ & $-5^{\mathrm{c}}$ & $16^{\mathrm{b}}$ & $32^{\mathrm{a}}$ \\
\hline
\end{tabular}

${ }^{1} \mathrm{mg} .100 \mathrm{ml}^{-1}$ anhydrous alcohol. Different letters in same row indicate statistical difference by Tukey's test at $5 \%$ significance.

Table 8. Chemical composition of single malt whiskies and cognac.

\begin{tabular}{lccccccccc}
\hline & Ethanol $^{1}$ & Copper $^{2}$ & Volatile acidity $^{3}$ & Furfural $^{3}$ & Aldehydes $^{3}$ & Esters $^{3}$ & Methanol $^{3}$ & High alcohols $^{3}$ & Congeners $^{3}$ \\
\hline Whisky A & 41.00 & 1.60 & 64.38 & 1.93 & 10.94 & 26.39 & 5.06 & 468.34 & 571.98 \\
Whisky B & 40.92 & 1.28 & 67.61 & 1.26 & 8.64 & 27.13 & 4.35 & 478.78 & 583.42 \\
Cognac & 40.52 & 3.04 & 86.33 & 2.20 & 7.97 & 40.44 & 11.38 & 438.61 & 575.55 \\
\hline
\end{tabular}

Whisky A: Glen Deveron Pure Highland Single Malt Aged 10 Years, William Lawson Distillers Ltd, Scotland. Whisky B: Aberfeldy Single Highland Malt Scotch Whisky Aged 12

Years, Aberfeldy Distillery, Scotland. Cognac: Remy Martin Fine Champagne Cognac VSOP, CLS Remy Cointreau, France. ${ }^{1}$ in $\% \mathrm{v} / \mathrm{v} 20^{\circ} \mathrm{C} ;{ }^{2}{ }^{2} \mathrm{ppm} ;{ }^{3} \mathrm{mg} .100 \mathrm{~mL}{ }^{-1}$ anhydrous alcohol. 
Table 9. Average scores assigned by appraisers to sensory parameters of the spirits.

\begin{tabular}{lcccc}
\hline & $\begin{array}{c}\text { Simple } \\
\text { distilled spirit }\end{array}$ & \multicolumn{3}{c}{$\begin{array}{c}\text { Spirit produced by double distillation } \\
\text { according to methodology }\end{array}$} \\
\cline { 3 - 5 } & & $10-80-10$ & Cognac & Whisky \\
\hline Flavour & $5,8^{\mathrm{b}}$ & $5,9^{\mathrm{b}}$ & $6,0^{\mathrm{b}}$ & $6,5^{\mathrm{a}}$ \\
Taste & $5,3^{\mathrm{c}}$ & $5,7^{\mathrm{bc}}$ & $6,2^{\mathrm{b}}$ & $6,8^{\mathrm{a}}$ \\
Preference $^{1}$ & 2 & 4 & 8 & 16 \\
\hline
\end{tabular}

${ }^{1}$ number of appraisers who preferred the respective spirit. Different letters in same row indicate statistical difference by the Tukey test at $5 \%$ significance.

\section{Conclusions}

Compared to simple distillation, the double distillation methodology improved the chemical quality of the spirits, since it provided reduction in the concentrations of volatile acidity, aldehydes, esters, methanol, higher alcohols, and consequently, the coefficient of congeners of the produced spirits.

The double distillation methodology also improved the sensory quality of spirits. Among the double distillation methodologies tested, the spirits produced by the methodology used for whisky production obtained the best sensory acceptance.

\section{Acknowledgements}

The authors are grateful to the FAPESP (The State of Sao Paulo Research Foundation) for the support provided.

\section{References}

BRASIL. Instrução Normativa n. 13, de 29 de junho de 2005. Diário Oficial da República Federativa do Brasil, Brasília, DF, 30 jun. 2005a.

BRASIL. Instrução Normativa n. 24, de 8 de setembro de 2005. Diário Oficial da República Federativa do Brasil. Brasília, DF, 9 set. 2005b.

GEROYIANNAKI, M. et al. Evaluation of acetaldehyde and methanol in greek traditional alcoholic beverages from varietal fermented grape pomaces (Vitis vinifera L.). Food Control, v. 18, p. 988-995, 2007. http://dx.doi.org/10.1016/j.foodcont.2006.06.005

LAMIABLE, D. et al. Acute methanol intoxication. EMC-Toxicologie Pathologie, v. 1, p. 7-12, 2004. http://dx.doi.org/10.1016/j. emctp.2003.10.001

LÉAUTÉ, R. Distillation in alambic. American Journal of Enology and Viticulture, v. 41, n. 1, p. 90-103, 1990.

MACFIE, H. J.; BRATCHELL, N. Designs to balance the effect of order of presentation and first order carry-over effects in hall tests. Journal of Sensory Studies, v. 4, p. 129-148, 1989. http://dx.doi. org/10.1111/j.1745-459X.1989.tb00463.x

MAIA, A. B. R. Componentes secundários da aguardente. STAB: Açúcar Álcool e Subprodutos, v. 12, n. 6, p. 29-34, 1994.

MIRANDA, M. B. et al. Perfil físico-químico de aguardente durante envelhecimento em tonéis de carvalho. Ciência e Tecnologia de Alimentos, v. 28, p. 84-89, 2008. Suplemento. http://dx.doi.org/10.1590/S0101-20612008000500014

NASCIMENTO, R. F. et al. Qualitative and quantitative highperformance liquid chromatographic analysis of aldehydes in Brazilian sugar cane spirits and other distilled alcoholic beverages. Journal of Chromatography A, v. 782, p. 13-23, 1997. http://dx.doi.org/10.1016/S0021-9673(97)00425-1

NOVAES, F. V. Em nome da qualidade da aguardente de cana. O Engarrafador Moderno, v. 7, n. 46, p. 68-73, 1997.

NYKÄNEN, L. Formation and occurrence of flavour compounds in wine and distilled alcoholic beverages. American Journal of Enology and Viticulture, v. 37, n. 1, p. 84-96, 1986.

PIGGOTT, J. R.; CONNER, J. M. Whiskies. In: LEA, A. G. H.; PIGGOTT, J. R. (Ed.) Fermented beverage production. 2. ed. New York: Klumer Academic/Plenum Publishers, 2003. cap. 11, p. 239-262.

PIMENTEL-GOMES, F.; GARCIA, C. H. Estatística aplicada a experimentos agronômicos e florestais: exposição com exemplos e orientações para uso de aplicativos. Piracicaba: FEALQ, 2002.

RODRÍGUEZ, R.; MANGAS, J. Obtención de aguardiente de sidra mediante alambique com columna de rectificación. Alimentaria, v. 77, p. 89-93, 1996.

STATISTICAL ANALYSIS SYSTEM INSTITUTE - SAS. Sas/Qc software: usage and reference. 2. ed. Cary: SAS Institute, 1996. 